УДК 342.951

DOI https://doi.org/10.32849/2663-5313/2021.2.17

\title{
Олексій Дніпров,
}

докт. юрид. наук,

провідний науковий співробітник

Науково-дослідного інституту публічного права

ORCID ID: 0000-0002-7157-9748

\section{КОРЕЛЯЦЯ КАТЕГОРІЙ «ДЕРЖАВНЕ УПРАВЛІННЯ ТА «ПУБЛІЧНЕ АДМІНІСТРУВАННЯ»}

Актуальність статті полягає в тому, що будь-якому явищу притаманні становлення та розвиток, що визначають певну зміну його якісно-кількісних характеристик, а також сутніснозмістовного складника. За таких обставин вказане явище належатиме завжди до актуально досліджуваних об'єктів або предметів наукових пошуків. Не є винятком і явище публічного адміністрування, яке протягом останніх років активно впроваджується в загальноправові «канони». При ивому воно прийшло на зміну явищу державного управління, що досить тривалий час було єдиним індикатором виконавчо-розпорядчої діяльності. Метою статті є здійснення корелячії правових категорій «державне управління» та «публічне адміністрування» шляхом розкриття їх дефінітивного тлумачення та сутнісного складника. Статтю присвячено кореляиії правових категорій «державне управління» та «публічне адміністрування» иляхом розкриття їх дефінітивного тлумачення та сутнісного складника. 3'ясовано, що натепер ведуться активні дискусії щодо визначення кореляиії означених категорій, оскільки одні науковиі визначають державне управління як складник публічного адміністрування, інші ж, навпаки, наголошують, що публічне адміністрування виступає формою або інструментом державного управління. Вказано, що попри намагання багатьма науковиями ототожнити ці категорії, вони не є ідентичними, а характеризуються особистими, притаманними лише їм, рисами. Зокрема, управління як базова категорія адміністративного права ідентифікується як імперативна вказівка, що передбачає безумовне виконання владно-управлінських рішень уповноваженого суб'єкта, тоді як адміністрування передбачає врахування людиноцентристської ідеологї̈, в межах якої публічна адміністрачія має враховувати інтереси суспільства під час прийняття рішень управлінського характеру. До того ж адміністрування, окрім безпосередньої виконавчо-розпорядчої діяльності, охоплює також діяльність, пов'язану з наданням приватним особам адміністративних послуг. Зроблено висновок, що зараз варто використовувати категорію «публічне адміністрування», яка за своїм змістом є ширшою, аніж категорія «державне управління».

Ключові слова: державне управління, публічне адміністрування, публічна адміністрація, виконавча влада, управління, адміністрування.

Постановка проблеми. Будь-якому явищу притаманні становлення та розвиток, що визначають певну зміну його якісно-кількісних характеристик, а також сутнісно-змістовного складника. За таких обставин вказане явище належатиме завжди до актуально досліджуваних об'єктів або предметів наукових пошуків. Не є винятком і явище публічного адміністрування, яке протягом останніх років активно впроваджується в загальноправові «канони». При цьому воно прийшло на зміну явищу державного управління, що досить тривалий час було єдиним індикатором виконавчо-розпорядчої діяльності. Зміна парадигми сучасного адміністративного права зумовлює необхідність кореля-

(C) О. Дніпров, 2021 ції означених понять, що й визначає актуальність цього дослідження.

Аналіз останніх досліджень і публікацій. Дослідженням державного управління, публічного адміністрування, їх взаємовідношенням займалося чимало науковців. Зокрема, серед основних з них варто виділити Н. Аврамчикову, В. Авер'янова, Г. Атаманчука, В. Бакуменка, О. Бандурку, В. Бодрова, Ю. Ковбасюка, Г. Купряшина, В. Мартиненко, М. Міненко, Ю. Оболенського, М. Пасічника, Ю. Римаренка, В. Соловйова, В. Чиркина, Ю. Шарова й інших. Проте сьогодні у наукових колах відсутнє уніфіковане бачення категорій «державне управління» та «публічне адміністрування». Саме тому у межах цього дослідження ми здійснимо спробу їх кореляції. 
Метою статті є здійснення кореляції правових категорій «державне управління» та «публічне адміністрування» шляхом розкриття їх дефінітивного тлумачення та сутнісного складника.

Виклад основного матеріалу. Перед тим, як перейти до безпосереднього розгляду матеріалу, доцільно визначити, що в цьому дослідженні під кореляцією розуміється «взаємна залежність, взаємний зв’язок, співвідношення, відповідність предметів, понять» [1, с. 287].

Зазначимо, що першочергово зарубіжна категорія «публічне адміністрування» (public administration) мала однозначне тлумачення й ототожнювалась 3 категорією «державне управління». Однак із часом науковою спільнотою було виявлено полісемантичний характер цієї категорії, та іï̈ переклад на державну мову визначався як «публічна адміністрація», «публічне адміністрування», «суспільне управління», «управління на державному та місцевому рівні», «громадська адміністрація» [2, с. 115]. Тобто, як бачимо, джерела публічного адміністрування пов'язані $з$ державним управлінням, але по-різному ідентифіковані залежно від перекладу та контексту.

За такої постановки проблеми необхідно визначити семантику вказаних понять. Зокрема, Великий тлумачний словник сучасної української мови визначає, що: управляти - це спрямовувати діяльність, роботу кого-, чого-небудь; бути на чолі когось, чогось; керувати [3, с. 1519]; адмініструвати керувати установою, організацією, підприємством тощо; управляти [3, с. $12-13] .3$ огляду на зазначене можна зробити висновок, що означені категорії є тотожними та фактично означають одне й те саме.

Проте у наукових колах дослідники дотримуються іншої позиції. Розглянемо основні наукові позиції щодо визначення тої або іншої категорії, а також безпосередне їх співвідношення й зіставлення. Так, відповідно до позиції В. Авер'янова державне управління - це особливий та самостійний різновид діяльності держави, що здійснює окрема система спеціальних державних органів - органів виконавчої влади [4, с. 6]. Тобто автор фактично зводить здійснення державного управління до виконавчо-розпорядчої діяльності, що відповідає традиційному розумінню категорії державного управління за радянських та пострадянських часів.

Своєю чергою Т. Коломоєць, досліджуючи державне управління, доходить висновку, що його варто розглядати у вузькому та широкому розумінні. Зокрема, у вузькому розумінні - це сукупність державних органів, між якими певним чином розподілені різні види діяльності держави. У широкому розумінні, державне управління - це вид соціального управління, вид специфічної діяльності держави, що дістає вияв у функціонуванні іï̈ органів, які впливають на суспільні відносини з метою їі урегулювання відповідно до державних інтересів [5, с. 121].

Г. Атаманчук вважав, що державне управління - це практичний, організуючий і регулюючий вплив держави, через систему своїх структур, на суспільну і приватну життєдіяльність людей з метою їі упорядкування, збереження або перетворення, що спирається на їі владну силу [6, с. 33].

Цікавими видаються погляди В. Бакуменка та Ю. Сурміна, які наголошують, що розуміння сутності державного управління зазнало еволюції внаслідок розвитку демократії та громадянського суспільства у світі та, зокрема, в Україні. Відтак сьогодні аспект взаємодії держави і громадянського суспільства в державному управлінні є дуже важливим, на відміну від традиційного бачення державного управління як організуючого і регулюючого впливу держави на суспільну життєдіяльність людей з метою її упорядкування, зберігання або перетворення, що спирається на її владну силу [7, с. 150]. Тобто 3 огляду на зазначене можна стверджувати, що сьогодні фактично відбувається трансформація державного управління у публічне адміністрування.

Водночас С. Чернов стверджує, що попри загальну синонімічність та вживаність у практично однакових випадках, категорії «управління» та «адміністрування» мають різне значення. Так, управління передбачає імперативність у процесі його впровадження, безумовність виконання та, як наслідок, прийняття управлінських рішень, обмеження прав у певних випадках меншої частини суспільства. Адміністрування ж слід розуміти як форму надання управлінської послуги, за якої враховуються інтереси всіх верств суспільства. Адміністрування має фундамент діалогічності, гнучкості у питаннях формування як конкретних управлінських рішень, так і стратегії розвитку держави або регіону загалом. У рафінованому вигляді в адмініструванні чиновник виступає лише найманим слугою, який задовольняє потреби суспільства, залишаючись при цьому незаангажованим однією 3 сторін [8, с. 21-22]. На нашу думку, із зазначеним можна погодитись лише частково, адже адміністрування, окрім визначеного автором кола повноважень, також передбачає можливість прийняття управлінських рішень. Однак їх 
основна особливість у тому, що вони мають враховувати люденоцентристський підхід.

У цьому контексті варто згадати про позицію Ю. Шарова, який досить влучно визначає, що адміністрування (administration) означає розподіл повноважень та обов'язків між учасниками процесу та інформаційнокомунікативне забезпечення вертикальної та горизонтальної координації між суб'єктами врядування [9, с. 7].

Н. Мельтюхова стверджує, що, на відміну від державного управління, публічне адміністрування - це цілеспрямована взаємодія публічних адміністрацій з юридичними і фізичними особами щодо забезпечення реалізації законів й підзаконних актів та виконання частини основних функцій: орієнтуючого планування, що визначає бажані напрями розвитку, створення правових, економічних та інших умов для реалізації інтересів учасників взаємодії, розподілу праці, кооперування і координування діяльності, моніторинг результатів [10, с. 78].

Своєю чергою В. Бакуменко розглядає управління як визначальну функцію публічного адміністрування. Зупинимося на цьому детальніше. Так, відповідно до поглядів автора управління - це сукупність неперервних взаємопов'язаних дій та функцій, спрямованих на забезпечення досягнення певних цілей, що утворюється внаслідок взаємодії органів державної влади та органів місцевого самоврядування (суб'єкти публічного адміністрування) з суспільством або між собою (об'єкти публічного адміністрування). Це насамперед процес вироблення та реалізації регулюючих, організуючих і контролюючих впливів у будь-яких сферах і галузях суспільства, що покладений в основу діяльності суб'єктів публічного управління. Його характеристики і властивості безпосередньо пов'язані зі становленням і розвитком системи державної та місцевої влади і суспільства та відображають як їх особливості, так і особливості відповідних управлінських (суб'єкт-об'єктних, суб'єкт-суб'єктних і об'єкт-суб'єктних) відносин у часовому та просторовому вимірі $[11$, с. 10$]$.

На противагу вказаному, низка науковців дотримуються протилежних поглядів. Так, Є. Болотіна вважає, що публічне адміністрування є одним із ключових інструментів здійснення державного управління [12, с. 31] В. Мартиненко вказує, що публічне адміністрування $є$ формою реалізації публічного управління, яке здійснюють представницькі органи демократичного врядування через свої виконавчі структури [13, с. 20-21]. Тобто сьогодні ведуться активні дискусії щодо визначення кореляції означених категорій, оскільки одні науковці визначають державне управління як складник публічного адміністрування, інші ж, навпаки, наголошують, що публічне адміністрування виступає формою або інструментом державного управління.

Н. Обушна, досліджуючи державне управління та публічне адміністрування, отримала такі висновки:

1. Державне управління:

- переважає адміністративний та організуючий вплив держави;

- недостатньо спирається на публічний сектор;

- виконує функції регулювання економічної, соціально-культурної та адміністративно-політичної сфер;

2. Публічне адміністрування:

- забезпечує реалізацію рішень органів влади;

- застосовує демократичні, публічні, ліберальні форми та методи управління суспільним, соціальним та економічним розвитком країни [14, с. 58].

Програмою розвитку ООН вказано, що категорія «публічне адміністрування» має дуальне тлумачення й означає: по-перше, цілісний державний апарат, що включає політику, правові норми, процедури, системи, організаційні структури тощо, який фінансується за рахунок державного бюджету і відповідає за управління і координацію роботи виконавчої гілки влади та її взаємодію з іншими зацікавленими сторонами в державі, суспільстві та зовнішньому середовищі; по-друге, управління та реалізація різних урядових заходів, що пов'язані з виконанням законів, постанов та рішень уряду та управління, що пов'язане 3 наданням публічних послуг [15].

Ведучи мову про публічне адміністрування, науковці виділяють такі його аспекти:

- вплив на систему державного адміністрування та місцевого самоврядування механізмів громадського контролю;

- співвіднесення інтересів загальнодержавних та місцевих, громадських та особистісних інтересів, та врахування їх впливу під час вироблення управлінських рішень;

- забезпечення здійснення громадської оцінки процесів розробки і виконання управлінських рішень [16, с. 190; 17, с. 63]

У цьому контексті доцільно вказати, що публічне адміністрування ідентифікується як теорія та практика державного управління, яка характеризується реалізацією адміністративних процедур шляхом публічної діяльності, застосування інструментів демократичного врядування, упорядкування суспільної діяльності та надання адміністративних послуг як засобу реалізації прав та свобод громадян, а також зазначено, що 
в Україні воно набуло офіційного визнання як освітня спеціальність [7, с. 605].

Крім того, необхідно зазначити, що під адміністрацією розуміється «керівний орган установи, організації, підприємства; виконавча влада» [3, с. 13]. 3 огляду на вказане варто також здійснити співставлення адміністрації (тобто фактично публічного адміністрування) із виконавчою владою.

За таких обставин необхідно навести систему суб'єктів публічної адміністрації:

- органи виконавчої влади вищого, центрального та місцевого рівнів;

- органи місцевого самоврядування;

- суб'єкти делегованих повноважень, до яких належать громадські об'єднання, та інші суб'єкти під час здійснення делегованих законодавством виконавчих функцій [18, c. 22-23]

Тобто органи виконавчої влади завжди належатимуть до публічної адміністрації, що здійснює публічне адміністрування. Проте не всі суб'єкти публічної адміністрації є органами виконавчої влади.

Отже, публічне адміністрування та виконавча влада не є тотожними, адже публічне адміністрування за своєю суттю ширше, а виконавча влада в цьому контексті та відповідно до функціонального призначення - це різновид публічного адміністрування та інститут публічної влади, який складається із сукупності публічних органів, що здійснюють владно-політичні та владно-управлінські функції у визначеній законодавством сфері.

\section{Висновки}

Таким чином, кореляція категорій «державне управління» та «публічне адміністрування» дозволяє стверджувати, що попри намагання багатьма науковцями ототожнити ці категорії, вони не є ідентичними, а характеризуються особистими, притаманними лише їм, рисами. Зокрема, управління як базова категорія адміністративного права ідентифікується як імперативна вказівка, що передбачає безумовне виконання владно-управлінських рішень уповноваженого суб'єкта, тоді як адміністрування передбачає врахування людиноцентристської ідеології, в межах якої публічна адміністрація має враховувати інтереси суспільства під час прийняття рішень управлінського характеру. До того ж адміністрування, окрім безпосередньої виконавчо-розпорядчої діяльності, охоплюе також діяльність, пов'язану з наданням приватним особам адміністративних послуг.

За таких обставин, а також враховуючи вищевикладене в науковому дослідженні, можна зробити висновок, що сьогодні варто використовувати категорію «публічне адмі- ністрування», яка за своїм змістом є ширшою, ніж категорія «державне управління».

\section{Список використаних джерел:}

1. Словник української мови : в 11 тт. / АН УРСР. Інститут мовознавства; за ред. І. Білодіда. Київ : Наукова думка, 1970-1980. Т. 4.587 с.

2. Колесникова К. Публічне адміністрування в Україні: огляд літературних джерел. Теорія та практика державного управління. 2013. Вип. 3. С. 112-119.

3. Великий тлумачний словник сучасної української мови; уклад. і голов. ред. В. Бусел. Київ ; Ірпінь : ВТФ «Перун», 2009. 1736 с.

4. Державне управління в Україні: навчальний посібник / за заг. ред. В. Авер'янова. Київ : Вид-во ТОВ «СОМИ», 1999. 265 с.

5. Коломоєць Т. Адміністративне право України. Академічний курс : підручник. Київ : Юрінком Інтер, 2011. 576 с.

6. Атаманчук Г. Теория государственного управления: курс лекций, 4-е изд., дополн. Москва : Омега-Л, 2006. 584 с.

7. Енциклопедичний словник 3 державного управління / уклад. : Ю. Сурмін, В. Бакуменко, А. Михненко та ін. ; за ред. Ю. Ковбасюка, В. Трощинського, Ю. Сурміна. Київ : НАДУ, 2010. 820 с.

8. Публічне управління та адміністрування в умовах інформаційного суспільства: вітчизняний і зарубіжний досвід: монографія / за заг. ред. C. Чернова, В. Воронкової, В. Банаха, О. Сосніна, П. Жукаускаса, Й. Ввайнхардт, Р. Андрюкайтене; Запоріз. держ. інж. акад. Запоріжжя : ЗДІА, 2016. 606 с.

9. Шаров Ю. Інноваційні інструменти публічного адміністрування: європейський контекст. Публічне управління: теорія та практика. Харків : ДокНаукДержУ Ур, 2010. № 1. С. 5-9.

10. Мельтюхова Н. Становлення і розвиток публічної адміністрації в Україні. Свропеїзація публічного адміністрування в Україні в контексті європейської інтеграції : матеріали наук.-практ. конф. 17 груд. 2009 р., м. Дніпропетровськ / за заг. ред. Л. Прокопенка. Дніпро : ДРІДУ НАДУ, 2009. 224 c.

11. Бакуменко В. Публічне адміністрування як процес вироблення, прийняття та виконання управлінських рішень. Наукові розвідки з державного та муніиипального управління. 2015, № 1. C. $8-26$.

12. Болотіна Є. Публічне адміністрування i менталітет українців. Вісник економічної науки України. 2016. № 2. С. 27-31.

13. Міненко М. Трансформація системи державного управління в сучасні моделі регулювання суспільства. Державне управління: удосконалення та розвиток. URL: http:// www.dy.nayka.com.ua/?op $=1 \& z=581$.

14. Обушна Н. Публічне управління як нова модель організації державного управління в Україні: теоретичний аспект. Ефективність державного управління. 2015. Вип. 44(1). С. 53-63. 
15. Програма розвитку OOH. URL: https://www.ua.undp.org/content/ukraine/uk/ home.html.

16. Формування державно-управлінських рішень: проблеми теорії, методології, практики: монографія / В. Бакуменко та ін. Київ : Вид-во УАДУ, 2000.328 с
17. Бондаренко К. Щодо питання визначення об'єкта державного управління. Юридичний вісник. 2014. № 6. С. 62-66.

18. Адміністративне право України. Повний курс: підручник / Галунько В., Діхтієвський П., Кузьменко О., Стеценко С. та ін. Видання друге. Херсон : ОЛДІ-ПЛЮС, 2019. 584 с.

Oleksii Dniprov. Correlation of categories "state management" and "public administration"

The relevance of the article is that any phenomenon is characterized by the formation and development that determine a certain change in its qualitative and quantitative characteristics, as well as the substantive component. In such circumstances, this phenomenon will always belong to the currently studied objects or objects of scientific research. The phenomenon of public administration, which has been actively introduced into common law "canons" in recent years, is no exception. At the same time, it replaced the phenomenon of public administration, which for a long time was the only indicator of executive and administrative activity. The aim of the article is to correlate the legal categories of "public administration" and "public administration" by disclosing their definitive interpretation and essential component. The article is devoted to the correlation of the legal categories "state management" and "public administration" by revealing their definitive interpretation and essential component. It has been found that there is currently an active debate on the correlation of these categories, as some scholars define state management as a component of public administration, while others, on the contrary, emphasize that public administration is a form or tool of state management. It is pointed out that despite the attempts of many scientists to identify these categories, they are not identical, but are characterized by personal, unique features. In particular, management as a basic category of administrative law is identified as an imperative instruction, which provides for the unconditional implementation of government decisions of the authorized entity, while administration involves taking into account the centrist ideology, within which public administration must take into account public interests in management decisions. Besides, administration, in addition to direct executive and administrative activities, also includes activities related to the provision of administrative services to individuals. It is concluded that today it is worth using the category of "state management", which in its content is broader than the category of "public administration".

Key words: state management, public administration, executive power, management, administration. 